ГРАБОВСЬКА В.М.

\title{
ПРІОРИТЕТНІСТЬ ФОРМ ВЛАШТУВАННЯ ДІТЕЙ-СИРІТ ТА ДІТЕЙ, ПОЗБАВЛЕНИХ БАТЬКІВСЬКОГО ПІКЛУВАННЯ
}

У науковій статті досліджено сутність та пріоритетність форм влаштування дітей-сиріт та дітей, які позбавлені батьківського піклування. Проаналізовані особливості застосування сімейних форм влаштування. 3 урахуванням досвіду європейських держав запропоновані пріоритетні напрями вдосконалення положень чинного сімейного законодавства.

Визначені основні положення національного сімейного законодавства закріплюють сімейні форми влаштування дітей: усиновлення, передача дитини до прийомної сім'ї, патронатної сім'ї, дитячого будинку сімейного типу, ознаки, що виступають основним критерієм їх розрізнення. Вказаний вплив ратифікованої Україною Конвенції про права дитини, що закріплює способи захисту прав дитини.

Розкрито суть усиновлення як однієї 3 найефективніших форм влаштування дітей, позбавлених батьківського піклування, специфіка якого полягає в тому, що усиновленою може бути не лише особа, яка наділена правовим статусом дитини, а й повнолітня особа, що не має матері, батька або позбавлена їх батьківського піклування. Основною засадою якої є дотримання таємниці усиновлення, яка не може розглядатися як інструмент обмеження прав дитини.

Встановлено, що перспективним напрямом застосування різних форм влаштування дітей, позбавлених батьківського піклування, є ратифікація Гаазької конвенції, що передбачає міждержавне співробітництво щодо усиновлення. Це передбачає вдосконалення національних норм для удосконалення правового регулювання усиновлення та інших альтернативних форм влаштування дітей, позбавлених батьківського піклування.

Здійснено порівняння форм влаштування дітей у державні установи та альтернативних форм влаштування дітей, а також з'ясовано, що договірною формою влаштування дітей $є$ патронат як угода щодо соціального обслуговування окремих категорій фізичних осіб, а також як спосіб встановлення опіки над особами, що відбули покарання у вигляді позбавлення волі на певний строк. Нині патронат над дитиною сприймається як тимчасовий догляд, виховання та реабілітація дитини в сім'ї патронатного вихователя на період подолання дитиною, іiі батьками або іншими законними представниками складних життєвих обставин.

У процесі цього дослідження ми дійшли висновку, що необхідне докорінне перетворення застарілої системи захисту дітей, що супроводжується ліквідацією мережі інтернатних закладів та повною їх заміною альтернативними формами.

Ключові слова: сімейні форми влаштування, особливості застосування, досвід європейських держсв, сімейне законодавство, пріоритетність.

The research examines the nature and priority of forming orphans and children who wish to use care. Taking into account the trusted European states, the priority areas for improving the provisions of pure family laws have been proposed.

The basic actions of the national family law define the family forms of arrangement of children: synchronization, transfer of the child to the present families, patronage families, orphanages of family type, designations which are the main arteries with their extension. Reference is made to the ratified Ukrainian Convention on the Rights of the Child, which sets out ways that are true to the child.

(C) ГРАБОВСЬКА В.М. - викладач циклової комісії юридичних дисциплін (Ірпінський державний коледж економіки та права) 
Reveal a significant upgrade as soon as the most effective forms of placement of placement of children deprived of great care are utilized by a specialist using pre-emptive, non-existent, Orthodox person status, and possibly a non-existent person in need of an answer or denied care. The main problem that remains the highest is the mystery, which cannot be addressed in its instruments limited by the truth of the child.

The comparison of forms of placement of children in public institutions and alternative forms of placement of children. It has also been found out that the contractual form of arranging children is patronage, as an agreement on social services for certain categories of individuals, as well as a way of establishing custody of persons who have served their sentence of imprisonment for a definite term. Now, child patronage is perceived as temporary care, upbringing and rehabilitation of a child in the family of a patron caregiver for the period of overcoming the child, his or her parents or other legal representatives of difficult life circumstances.

In the course of this study, we came to the conclusion that there is a need for a radical transformation of the outdated child protection system, which is accompanied by the elimination of the network of residential care institutions and their complete replacement by alternative forms.

Key words: family forms of arrangement, application features, experience of European states, family law, priority, adoption, patronage, receptive family, orphanage of family type.

Вступ. Охорона та захист особистих немайнових і майнових прав дітей-сиріт та дітей, позбавлених батьківського піклування, досить часто стає предметом дослідження вчених. Це зумовлено, передусім, тим, що такі діти через їхній вік та умови проживання $є$ найбільш уразливою категорією населення. Тому держава Україна на рівні Конституції [1, ст. 52] взяла на себе обов'язок з утримання та виховання дітей-сиріт і дітей, позбавлених батьківського піклування. Нині в Україні є багато можливостей для влаштування дітей-сиріт та дітей, позбавлених батьківського піклування.

Однак процеси реформування інтернатної системи зумовили необхідність переглянути нормативно закріплені форми сімейного влаштування і внести відповідні зміни до чинного законодавства з урахуванням міжнародного досвіду. Наявна система контролю за усиновлювачами, батьками-вихователями, прийомними батьками, патронатними вихователями має свої недоліки, що призводить до зростання кількості звернень до Європейського суду з прав людини після вичерпання всіх національних інструментів правового захисту.

Постановка завдання. Метою статі є здійснити аналіз особливостей застосування сімейних форм влаштування, запропонувати пріоритетні напрями вдосконалення положень чинного сімейного законодавства з урахуванням здобутків передових європейських держав.

Питання про сімейні форми влаштування дітей-сиріт та дітей, позбавлених батьківського піклування, були предметом дослідження як вітчизняних, так і зарубіжних вчених. До першої групи можна зарахувати Ю.С. Червоного, 3.В. Ромовську, О.І. Карпенка, В.Ю. Москалюка, А.М. Нечаєва, I.А. Бірюкова та інших представників цього напряму досліджень. Серед іноземних дослідників доцільно виокремити Х. Меркадала і В. Голдфарба, які вивчали проблемні аспекти патронатного виховання. Проте розвиток та функціонування різних форм влаштування дітей-сиріт та дітей, позбавлених батьківського піклування, в порівняльному аспекті не був предметом дослідження фахівців у галузі права.

Результати дослідження. Положення національного сімейного законодавства закріплюють такі сімейні форми влаштування дітей: усиновлення, передача дитини до прийомної сім’і, патронатної сім'ї, дитячого будинку сімейного типу. Кожна з них має характерні ознаки, що виступають основним критерієм розрізнення. Водночас їх існування пов'язане, в тому числі, 3 ратифікацією Україною Конвенції про права дитини, що закріплює вищезазначені способи захисту прав дитини.

Розглянемо, першу форму влаштування дітей-сиріт та дітей, позбавлених батьківського піклування, - усиновлення. Згідно з Свропейською конвенцією про усиновлення дітей, усиновлення застосовується до дитини, яка на момент звернення усиновлювача ще не досягла 18 років, не перебуває й не перебувала в шлюбі, в зареєстрованому партнерстві й не досягла повноліття [7]. Україна як держава-учасниця цієї конвенції приєдналася до ії положень, серед яких на осо- 
бливу увагу заслуговує питання боротьби з невиправданими фінансовими вигодами, пов'язаними з усиновленням, застосування тотожних гарантій і норм при усиновленні всередині країни та за ії межами, надання дозволу на проведення цієї процедури тільки компетентними органами.

Відповідно до ч. 2 ст. 207 Сімейного кодексу України усиновлення дитини провадиться в її найвищих інтересах для забезпечення стабільних та гармонійних умов їі життя [2]. Специфіка цієї форми влаштування полягає в тому, що усиновленою може бути не лише особа, яка наділена правовим статусом дитини, а й повнолітня особа, що не має матері, батька або позбавлена їх батьківського піклування. Згідно з ч. 1 ст. 225 Сімейного кодексу України, усиновлення вважається здійсненим у день набрання чинності рішенням суду про усиновлення [2].

Якщо дитина вважає усиновлювачів своїми батьками, ці відносини не відрізняються від родинних. Якщо ж дитина знає про те, що усиновлювачі не є іiі рідними батьками, фактичні відносини між ними можуть бути дещо іншими. Цей принцип не $є$ порушенням права дитини знати своїх батьків, оскільки особа, яка була усиновлена, має право після досягнення чотирнадцяти років на одержання інформації щодо свого усиновлення.

Нормативне закріплення вікових вимог до усиновлювача спрямоване на те, щоб переконатися в його змозі забезпечити належний рівень виховання та всебічного розвитку усиновленого. Водночас емансипована особа не може бути усиновлювачем, що пояснюється відсутністю в неї, перш за все, належного рівня психологічної підготовки до виховання дитини.

Ця сімейна форма влаштування передбачає втрату правових зв'язків із біологічними батьками, а також родичами за походженням, однак не можна говорити про нівеляцію самої природи людини, адже усиновлення, як і будь-який інший правовий акт, не скасовує законів генетики, тому в разі втрати правових зв'язків із кровними родичами не розривається біологічна спорідненість.

Однією з цілей усиновлення є створення сприятливих умов для повноцінного життя та розвитку дитини, тому Україна здійснила рецепцію положень іноземного законодавства щодо виокремлення категорії осіб, які мають переважне перед іншими особами право на усиновлення. Особливу позицію серед них займає усиновлення громадянином України кількох дітей, що $є$ братами, сестрами, який є родичем дитини [8, с. 475]. Це пояснюється тим, що держава, перш за все, враховує інтереси дитини, оскільки адаптація усиновленого швидше буде проходити в умовах присутності осіб, з якими він має кровний та стійкий емоційний зв'язок.

Наступна форма влаштування дітей-сиріт та дітей, позбавлених батьківського піклування, - патронат, який на початковому етапі формування національного сімейного законодавства тлумачився як форма соціального обслуговування окремих категорій фізичних осіб, а також як спосіб встановлення опіки над особами, що відбували покарання у вигляді позбавлення волі на певний строк. Але згодом цей термін набув сучасного значення. Так, згідно з ч. 1 ст. 252 Сімейного кодексу України, патронат над дитиною сприймається як тимчасовий догляд, виховання та реабілітація дитини в сім'ї патронатного вихователя на період подолання дитиною, її батьками або іншими законними представниками складних життєвих обставин [2].

На відміну від усиновлення, патронат характеризується тим, що він не має своїм наслідком виникнення батьківських прав у патронатного вихователя; юридичною підставою встановлення цієї форми влаштування є договір, який не належить до цивільно-правових угод; наявний строковий характер влаштування дитини - три місяці, який може бути продовжений органом опіки та піклування загалом до шести місяців; патронатний вихователь, на противагу усиновлювачу, отримує плату за виховання дитини; між патронатним вихователем та дитиною не виникає аліментних зобов'язань; патронат не є перешкодою для всиновлення.

Специфікою вищезазначеної сімейної форми влаштування є наявність договору, предметом якого є прийняття дитини в сім'ю і забезпечення її належним сімейним вихованням. Водночас, незважаючи на строковий характер угоди, дитина може бути залишена в родині патронатного вихователя і після досягнення нею повноліття, але вже на іншій правовій підставі.

Патронатним вихователем може бути громадянин України, який має досвід виховання дитини, відповідні житлові умови для надання послуг із догляду, виховання та реабілітації дитини у своєму помешканні [3].

На практиці доволі часто зустрічаються проблемні ситуації, пов'язані з тим, що в родині кандидата в патронатні вихователі вже $\epsilon$ діти. У цьому разі соціальний заклад проводить оцінку потреб дитини та ії сім’ї за формою, встановленою Міністерством соціальної політики України. 3 метою уникнення деструктивних проявів у процесі влаштування дитини в сім'ю патронатного вихователя було нормативно закріплено вимогу подання кандидатом довідки про відсутність 
судимостей, висновку про стан здоров'я, документа, що підтверджує право власності або право на користування житловим приміщенням. Такий підхід $є$ черговим підтвердженням того, що держава враховує інтереси дитини і дбає про те, аби її перебування у сім’ї патронатного вихователя було безпечним та комфортним.

Згідно з Порядком створення та діяльності сім’ї патронатного вихователя, влаштування, перебування дитини в сім'ї патронатного вихователя під час розгляду комісією з питань захисту прав дитини питання влаштування в сім’ю патронатного вихователя дитини з інвалідністю, з ураженням опорно-рухового апарату, порушенням зору, слуху обов'язково береться до уваги доступність житла патронатного вихователя для такої дитини, а також готовність патронатного вихователя здійснювати патронат над такою дитиною [3].

Правовою підставою виникнення між патронатним вихователем та дитиною відносин, які регулюються сімейним законодавством, є договір патронату. Для його чинності достатньо письмового викладення умов, підписів уповноважених представників органу опіки та піклування й патронатного вихователя, а також печатки органу опіки та піклування. Правочин належить до категорії оплатних, бо за виконання своїх функцій патронатний вихователь отримує щомісячну оплату. Ї̈і розмір залежить від багатьох факторів: вік, стан фізичного та психічного здоров’я дитини, рівень інтелектуального розвитку тощо. 3 цього питання 3. Ромовська зазначила, що плата за виховання, обслуговування дитини, тобто за виконану роботу та надані послуги, і кошти на утримання дитини - це різні речі $[8$, с. 474$]$.

Третьою сімейною формою влаштування дітей $є$ передача дитини до прийомної сім'ї та дитячого будинку сімейного типу. Процеси реформування чинної інтернатної системи супроводжуються зростанням значення прийомних сімей та дитячих будинків сімейного типу, що підтверджується відповідними статистичними даними. Так, станом на нинішній рік їх кількість в Україні порівняно з 2016 роком зросла на 4,3\% [4]. 3 одного боку, такі показники можуть розглядатися як свідчення того, що громадяни усвідомили необхідність надання допомоги соціально вразливим верствам населення. 3 іншого ж боку, механізм матеріального стимулювання, який запроваджений державою, в багатьох випадках займає домінуючу позицію під час прийняття відповідного рішення.

Згідно з Сімейним кодексом України, прийомною сім'єю є сім'я, яка добровільно взяла на виховання та спільне проживання від одного до чотирьох дітей-сиріт і дітей, позбавлених батьківського піклування [2]. Обмеження кількості дітей, що можуть одночасно перебувати в родині прийомних батьків, має на меті надати належну увагу кожному вихованцю. Як і дитячі будинки сімейного типу, вони створюються для надання послуг із сімейного обслуговування, адже прийомні батьки отримують фінансову допомогу зі сторони держави. Найбільш проблематичним у цьому напрямі $є$ питання недопущення перетворення цієї сімейної форми влаштування на бізнес.

У Постанові Кабінету Міністрів України «Про затвердження Положення про прийомну сім'ю» зазначається, що особи, які виявили бажання стати прийомними батьками, в обов'язковому порядку мають пройти навчання, організоване обласними центрами соціальних служб для сім'ї, дітей та молоді із залученням спеціалістів із питань психології, педагогіки, медицини тощо [3].

Під дитячим будинком сімейного типу розуміють окрему сім’ю, що створюється за бажанням подружжя або окремої особи, яка не перебуває у шлюбі, для забезпечення сімейним вихованням та спільного проживання не менш як п'яти дітей-сиріт і дітей, позбавлених батьківського піклування [5]. Незважаючи на те, що Сімейним кодексом України не встановлено верхньої межі чисельності дітей, стосовно яких може бути застосована ця форма сімейного влаштування, до Положення про дитячі будинки сімейного типу було внесене доповнення, згідно з яким закріпилася верхня межа у кількості 10 дітей. Це детерміновано численними випадками зловживань батьків-вихователів, які, отримуючи плату за свої послуги, не забезпечували дітей всім необхідним.

Окрім чисельності вихованців, дитячі будинки сімейного типу відрізняються від прийомних сімей тим, що батькам-вихователям для потреб дитячого будинку сімейного типу позачергово надається обладнаний індивідуальний житловий будинок або багатокімнатна квартира за нормами, встановленими законодавством [4].

Протягом тривалого часу, коли була відсутня вимога щодо подання соціальним закладам документів про наявність права власності на певне житлове приміщення, ця сімейна форма влаштування часто використовувалася батьками-вихователями як спосіб вирішення житлового питання. 
Отже, у XXI столітті в Україні триває процес модернізації способів організації прийомних сімей та дитячих будинків сімейного типу. Збільшення їх чисельності пов'язано зі спрямованістю держави на нівеляцію мережі інтернатних закладів та заміною їх альтернативними сімейними формами влаштування.

Якщо аналізувати міжнародний досвід захисту дітей-сиріт та дітей, позбавлених батьківського піклування, ми спостерігаємо дієвий механізм створення сприятливих умов для формування індивідуальності дітей, які опинилися в складних життєвих обставинах, де передбачено деінституалізацію, тобто докорінну перебудову застарілої системи захисту дітей, що супроводжується ліквідацією мережі інтернатних закладів та повною їх заміною альтернативними формами сімейного влаштування. Така політика визнана пріоритетною у США, країнах Східної Європи та СНД.

Основним аргументом провідних іноземних фахівців у цьому напрямі $є$ те, що колективний спосіб виховання дітей в інтернатних установах призводить до вкрай негативних психологічних наслідків для нової генерації - депривації. Водночас цікавим із позиції застосування сімейних форм влаштування дітей $\epsilon$ досвід США, де за рахунок досліджень В. Голдфарба було експериментально підтверджено шкідливість колективної форми виховання дитини. Так, ще в 1909 році в цій країні пролунала критика інтернатних закладів, оскільки вони поглинали значну частину дохідної частини бюджету, тоді як прийомні сім’ї, які вже існували на той час, вимагали значно менших фінансових витрат. Це зумовило прийняття Social Security Act, який передбачав матеріальну підтримку сімей із дітьми, що потрапили у складні життєві обставини [9, с. 24].

Також важливе місце займає діяльність Європейського суду з прав людини. До нього можна звертатися для захисту своїх прав тоді, коли вичерпані всі національні інстанції. Нині у провадженні цієї судової установи міжнародного рівня знаходиться значна кількість справ громадян України до держави у частині оспорювання правомірності дій останньої при реалізації процедур усиновлення, прийняття дитини до прийомної, патронатної сім’ї, дитячого будинку сімейного типу. Відповідно до останніх статистичних даних наша держава займає п'яте місце серед інших країн за кількістю звернень до Європейського суду з прав людини [6].

Такі тенденції, з одного боку, свідчать про недосконалість національного сімейного законодавства, низький рівень правової культури, поширення випадків зловживання посадовими особами своїми повноваженнями при виконанні покладених на них завдань. Але, якщо поглянути на ситуацію під іншим кутом зору, можна також простежити в цих показниках підтвердження бажання українців досягти справедливості при правозастосуванні.

На нашу думку, пріоритетним напрямом вдосконалення положень чинного сімейного законодавства $є$ ратифікація Гаазької конвенції про захист дітей та співробітництво в галузі міждержавного усиновлення, яка набула чинності у 89 державах та встановлює основні гарантії щодо недопущення викрадення, продажу або торгівлі дітьми, які можуть усиновлюватися.

Приєднання нашої держави до Гаазької конвенції дасть змогу перейти на якісно новий рівень у частині охорони дітей, які були прийняті в родини іноземних громадян на правах дочки чи сина. Так, до переваг таких заходів можна зарахувати такі: запровадження новітніх процедур із метою недопущення неправомірної фінансової вигоди; перевірка того факту, що дитина дійсно може усиновлюватися і що ця процедура є найкращим варіантом для неї; підбір прийнятної сім'ї для дитини; забезпечення збереження інформації стосовно дитини та ії біологічних батьків; перевірка добровільності згоди біологічних батьків на усиновлення.

Наступним пріоритетним напрямом є закріплення верхньої вікової межі потенційного усиновлювача. У Сімейному кодексі України до внесення змін існувало положення, згідно 3 яким не допускалося усиновлення особами, якщо різниця у віці між ним та усиновленим перевищує сорок п'ять років. У цьому контексті законодавці посилалися на те, що таке обмеження має дискримінаційний характер і не дає рівних можливостей особам реалізувати своє право бути усиновлювачами. Однак чинне сімейне законодавство грунтується на такому основоположному принципі, як захист інтересів дитини. На практиці неодноразово траплялися випадки, коли особи похилого віку брали у свою родину дитину на правах дочки чи сина, а потім через деякий час відмовлялися від неї, оскільки за станом здоров'я не мали змогу виконувати батьківські функції.

Черговим напрямом $\epsilon$ підвищення рівня відповідальності працівників органів опіки та піклування й інших суб'єктів, уповноважених державою на виконання контрольних функцій під час застосування відповідної сімейної форми влаштування. Незважаючи на закріплення дисциплінарної, кримінальної, майнової відповідальності зазначених осіб, все ж таки у практичній площині порушення порядку усиновлення, укладення патронатного договору, нездійснення не- 
обхідних перевірок для з'ясування умов проживання дітей супроводжується лише попередженням або звільненням особи як найтяжчого заходу впливу [10, с. 37]. Більш доцільно використовувати систему штрафних санкцій, що б поєднувалася із заходами матеріального стимулювання за сумлінне виконання покладених на особу посадових обов'язків.

Окрім цього, доцільно закріпити в Сімейному кодексі України норму, відповідно до якої усиновлення буде можливим, якщо дитина перебувала у сім'ї усиновлювача протягом певного проміжку часу на підставі застосування патронатного виховання, інститутів прийомної сім’і чи дитячого будинку сімейного типу. Передові європейські країни вже протягом багатьох років рухаються в цьому напрямі і саме у таких заходах вбачають спосіб подолання невиправданих відмов від дитини, яка була прийнята особою на правах дочки чи сина. Такі превентивні заходи продемонстрували свою дієвість на прикладі інших країн, у яких зменшилася кількість відмов майже на $85 \%$. Тому перспективним напрямом для України є здійснення рецепції цього застереження з урахуванням специфіки побудови національного сімейного законодавства.

Важливо зазначити, що інтернатні заклади неспроможні на високому рівні забезпечити вихованців всім необхідним для повноцінного фізичного, інтелектуального, емоційного розвитку. Як свідчить статистика, інтернатні заклади у багатьох випадках $є$ осередком виникнення кримінальних субкультур, тому не можна говорити про дієвість цієї форми виховання дитини. Звісно, заміна мережі інтернатних закладів альтернативними сімейними формами влаштування, що зазнає апробації в окремих регіонах, сприяє ефективнішому вихованню дітей, які опинилися в складних життєвих обставинах. Але необхідно врахувати й той факт, що у видатковій частині державного бюджету були закладені фінансові ресурси на реалізацію експериментальної програми деінституалізації інтернатних закладів.

Водночас сутність проблемного аспекту полягає у тому, що зменшення або взагалі невиділення державою коштів на наступні роки поставить під загрозу всю систему альтернативного виховання. Як наслідок, діти, влаштовані в нові родини, навряд чи без матеріальної підтримки держави залишатимуться у сім'ях усиновителів, прийомних батьків, батьків-вихователів або патронатних вихователів.

Таким чином, більш раціональним є здійснення поступової деінституалізації інтернатних закладів, що б поєднувалося 3 поширенням альтернативних сімейних форм влаштування. Держава має спрямувати свою діяльність на те, аби домінуючу позицію серед інших форм займало саме усиновлення, бо воно супроводжується настанням більш сприятливих для дитини правових наслідків.

Висновки. Однією з найбільш поширених форм сімейного влаштування дітей є усиновлення, що передбачає наділення усиновлювача правами й обов'язками батьків. Основною засадою при здійсненні цієї правової процедури є дотримання таємниці усиновлення, яка не може розглядатися у вигляді інструменту обмеження прав дитини, оскільки 3 чотирнадцяти років усиновлений наділяється правом отримання інформації, в тому числі у судовому порядку, про своїх біологічних батьків.

Патронатне виховання в Україні набуло поширення порівняно нещодавно, що детермінується створенням сприятливих умов для надання послуг патронатним вихователем. Його призначення - реабілітація, виховання дитини на час подолання нею чи біологічними батьками складних життєвих обставин. Фактично патронатне виховання являє собою спосіб надання послуг із сімейного обслуговування, що провадиться на платній основі.

Проблемні аспекти щодо функціонування прийомних сімей та дитячих будинків сімейного типу зумовлені здебільшого механізмом матеріального стимулювання, що призводить до перетворення їх на бізнес, головною ціллю якого є отримання прибутку. В ідеальному вигляді прийомні сім’i, дитячі будинки сімейного типу мають бути лише перехідним етапом до встановлення домінуючої форми сімейного влаштування - усиновлення.

3 метою удосконалення механізму застосування альтернативних сімейних форм виховання необхідно ратифікувати численні міжнародні конвенції, що гарантують захист від торгівлі дітьми, щодо яких застосовується відповідна сімейна форма влаштування, недопущення їх експлуатації. Перспективним напрямом є здійснення ратифікації Гаазької конвенції, яка передбачає міждержавне співробітництво з питань усиновлення, одним із напрямків якого вважається міждержавний обмін інформацією про стан усиновлених. Усунення деструктивних елементів у процесі застосування сімейних форм влаштування дітей можливе за умови застосування найбільш актуальних положень, що містяться в законодавстві інших країн та відображають досвід їх правотворчості. 


\section{Список використаних джерел:}

1. Конституція України: Закон України від 28 червня 1996 p. URL: http://zakon0.rada.gov.ua/ laws/show/254к/96-вp/page4 (дата звернення 21.11.2019 р.)

2. Сімейний кодекс України від 10 січня 2002 р. № 2947-III. URL: http://zakon3.rada.gov.ua/ laws/show/2947-14/page6 (дата звернення 21.11.2019 p.)

3. Про затвердження Положення про прийомну сім'ю : Постанова Кабінету Міністрів України від 26 квітня 2002 р. № 565. URL: http://zakon3.rada.gov.ua/laws/show/565-2002-n (дата звернення 22.11.2019 р.)

4. Про затвердження Положення про дитячий будинок сімейного типу : Постанова Кабінету Міністрів України від 26 квітня 2002 р. № 564 URL: http://zakon0.rada.gov.ua/laws/show/ 564-2002-n (дата звернення 22.11.2019 р.)

5. Про затвердження Порядку створення та діяльності сім'ї патронатного вихователя, влаштування, перебування дитини в сім'ї патронатного вихователя : Постанова Кабінету Міністрів України від 16 березня 2017 р. № 148. URL:http://zakon5.rada.gov.ua/laws/show/148-2017-n (дата звернення 25.11.2019 р.)

6. Українське незалежне інформаційне агентство новин: Статистика усиновлення дітейсиріт та дітей, позбавлених батьківського піклування в Україні. URL: https:/health.unian.ua/ country/1318291-v-ukrajini-ponad-73-tisyachi-ditey-sirit.html (дата звернення 25.11.2019 p.)

7. Про ратифікацію Європейської конвенції про усиновлення дітей : Закон України від 15 лютого 2011 р. № 3017-VI. URL: http://zakon3.rada.gov.ua/laws/show/994_a17 (дата звернення 25.11.2019 p.)

8. Ромовська 3.В. Сімейний кодекс України: Науково-практичний коментар. 2014. C. $474-480$.

9. Драгневич Л. Деякі аспекти законодавчого врегулювання проблеми влаштування неповнолітніх дітей, позбавлених батьківського піклування. Мала енииклопедія нотаріуса. 2016. № 5 (4). 24 c.

10. Опіка над дітьми в добу трансформації суспільного устрою / Завгородня Т.К., Лисенко Н.В., Мажец Д.-К., Ступарик Б.М. Івано-Франківськ - Ужгород : «Мистецька лінія», 2014. 152 с.

\section{СУТНІСНІ ЕЛЕМЕНТИ ПОРУШЕННЯ ПРАВА ОСОБИ НА СВОСЧАСНЕ СУДОЧИНСТВО: ОКРЕМІ ПІДХОДИ НАЦІОНАЛЬНОЇ СУДОВОЇ СИСТЕМИ}

Ця наукова стаття присвячена дослідженню актуального питання правової обгрунтованості та соціальної прийнятності різноманітних факторів, які спричиняють досить тривалі затримки судового процесу. У такий спосіб істотно порушується основоположне право людини на отримання своєчасного правосуддя, яке передбачене у ст. 6 Конвенції про захист прав людини й основоположних свобод. Європейський суд ыз прав людини, який покликаний застосовувати та тлумачити конвенційні принципи, у своїй практиці вказує, що будь-які процесуальні невиправдані затримки у розгляді справи є серйозним порушенням права особи на справедливий суд. У цьому контексті в роботі проведено аналіз темпоральних порушень правил про правову визначеність судочинства 3 боку вищого судового органу України - Верховного Суду. Піддано критиці часом невиправдане та досить тривале в часі коригування усталених та напрацьованих судових підходів щодо зміни підсудності окремих категорій справ. По-перше, це часто $є$ штучною процедурою,

( ) ГУЙВАН П.Д. - кандидат юридичних наук, заслужений юрист України, професор (Полтавський інститут бізнесу) 